Original Article

\title{
An overview of the taxonomic instability of endangered Golden and Zhobi mahseer in Pakistan
}

\author{
Uma visão geral da instabilidade taxonômica do golden em perigo e do Zhobi mahseer \\ no Paquistão
}

\author{
M. Yousafa (1), Z. Hasanª (1), F. Zaidia (1) and S. B. Rasheed ${ }^{* *}$ (1) \\ aUniversity of Peshawar, Department of Zoology, Peshawar, Pakistan
}

\begin{abstract}
In South and South East Asia three genera of fish species i.e. Tor, Neolissochilus and Naziritor are commonly known as Mahseer with at least 47 species. Among these 23 belongs to genus Tor, 22 to Neolissochilus and one to Naziritor i.e. Naziritor zhobensis. Recently another species added to genus Naziritor is Naziritor chelynoides in India. Among Tor species Tor putitora (Hamilton) is the most widely distributed Mahseer in Pakistan and other countries of the Indian subcontinent. However, based alone on morphological characters some authors identify the Pakistani counterparts as Tor macrolepis (Heckel), (a species presumed to be found exclusively in the Indus River system) distinct from Tor putitora (a species found in Ganga Brahmaputra River system). In order to resolve this taxonomic ambiguity, present study carried out meristic and morphometric measurements of Mahseer collected from a total of 11 water bodies of Pakistan. Ratios between the morphometric characters were calculated and statistically analyzed using t-test and correlation coefficient. Two species identified as Tor putitora and Naziritor zhobensis were the sole Mahseer inhabitants of Indus system in Pakistan. Tor putitora occurred at all surveyed sites while Nazirtor zhobensis had a distribution range from river Zhob to tributaries of river Gomal the right bank tributaries of River Indus. The study corroborates that there are no unequivocal morphological synapomorphies in any existing populations of both species. The study further demonstrates that head length, a character frequently used in Mahseer taxonomy, is not a good measure for species identification. Finally the present study establishes that Naziritor zhobensis still exists in the water bodies of Pakistan and that golden Mahseer occurring in Indus riverine system of Pakistan is Tor putitora.
\end{abstract}

Keywords: Indus Riverine system, morphology, Naziritor zhobensis, Pakistan, Tor putitora.

\section{Resumo}

No sul e sudeste da Ásia, três gêneros de espécies de peixes, ou seja, Tor, Neolissochilus e Naziritor, são comumente conhecidos como Mahseer com pelo menos 47 espécies. Entre estas, 23 pertencem ao gênero Tor, 22 a Neolissochilus e um a Naziritor, ou seja, Naziritor zhobensis. Recentemente, outra espécie adicionada ao gênero Naziritor é Naziritor chelynoides na Índia. Entre as espécies de Tor, Tor putitora (Hamilton) é o Mahseer mais amplamente distribuído no Paquistão e em outros países do subcontinente indiano. No entanto, com base apenas em caracteres morfológicos, alguns autores identificam as contrapartes paquistanesas como Tor macrolepis (Heckel) (uma espécie que se presume ser encontrada exclusivamente no sistema do rio Indo), distinta de Tor putitora (uma espécie encontrada no sistema do rio Ganga Brahmaputra). A fim de resolver essas ambiguidades taxonômicas, o presente estudo realizou medidas merísticas e morfométricas de Mahseer coletadas em um total de 11 corpos d'água do Paquistão. As razões entre os caracteres morfométricos foram calculadas e analisadas estatisticamente usando o teste t e o coeficiente de correlação. Duas espécies identificadas como Tor putitora e Naziritor zhobensis foram os únicos habitantes Mahseer do sistema fluvial Indo no Paquistão. Tor putitora ocorreu em todos os locais pesquisados, enquanto Nazirtor zhobensis tinha uma faixa de distribuição do rio Zhob aos afluentes do rio Gomal, afluentes da margem direita do rio Indo. O estudo corrobora que não há sinapomorfias morfológicas inequívocas em nenhuma das populações existentes de ambas as espécies. O estudo demonstra ainda que o comprimento da cabeça, um caractere frequentemente usado na taxonomia de Mahseer, não é boa medida para identificação das espécies. Finalmente, o presente estudo estabelece que Naziritor zhobensis ainda existe nos corpos d'água do Paquistão e que o Mahseer dourado ocorrendo no sistema fluvial Indo do Paquistão é Tor putitora.

Palavras-chave: sistema Riverine Indus, morfologia, Naziritor zhobensis, Paquistão, Tor putitora.

*e-mail: basitrasheed@uop.edu.pk

Received: September 26, 2020 - Accepted: February 24, 2021

This is an Open Access article distributed under the terms of the Creative Commons Attribution License, which permits unrestricted use, distribution, and reproduction in any medium, provided the original work is properly cited. 


\section{Introduction}

The fish belonging to three genera i.e. Tor, Neolissochilus and Naziritor are generally known as Mahseer, a game and food fish naturally found in Nepal, Pakistan, India, Sri Lanka, Bangladesh, Myanmar, China, Thailand, Laos, Cambodia, Vietnam, Indonesia and Malaysia (Shrestha, 1990). The fish species of genus Tor are considered true Mahseer due to the possession of median lobe (Ng, 2004). Naziritor zhobensis was first time reported by Mirza (1967) as Tor zhobensis from the Zhob River and is commonly known as the Zhobi Mahseer. Later on Mirza and Javed (1985) placed it in a new genus Naziritor. Although the Zhobi mahseer is endemic to Pakistan, it has not been reported from the country since its first report by Mirza (1967). According to Sati et al. (2013) there are 47 species, commonly referred to as Mahseer, i.e. 23 belongs to genus Tor, 22 to the genus Neolissochilus and one only to genus Naziritor i.e. Naziritor zhobensis but Khare et al. (2014) added another species to genus Naziritor i.e. Naziritor chelynoides. According to Desai (2003) seven Mahseer species are known from the Indian subcontinent to which Pakistan belong. These are Tor putitora (Hamilton, 1822), T. tor (Hamilton, 1822), T. mosal (Hamilton, 1822), T. mussullah (Sykes, 1839), T. khudree (Sykes, 1839), T. kulkarnii (Menon, 1992) and T. progeneius (McClelland, 1839). However, Dinesh et al. (2010) described five species on morphometric analysis and excluded Tor mosal and T. kulkarnii. Most of the species belonging to genus Tor are included in threatened list of IUCN (Lakra et al., 2010).

Tor putitora Hamilton, 1822 is widely distributed in Pakistan, India, Kashmir, Afghanistan, Bangladesh, China, Thailand and Malaysia (Khajuria and Langer, 2016). Sarma et al. $(2014,2015)$ described it as the carp with characteristic big scales and lateral line scales ranging from 24 to 28 , head length equal, greater or less than body depth, fleshy lips, median lobe and two pairs of barbels. According to Chatta and Ayub (2010) the golden Mahseer present in river systems of Pakistan is different from those present in other rivers of subcontinent and identified them as Tor macrolepis Heckel, 1838. The same statement was then confirmed by Pervaiz et al., (2012) but the findings were based on morphological characters like thick lips and head length more than body depth as described by Mirza (2004). Mirza (2004) stated that the golden Mahseer present in Indus River system of Pakistan is Tor macrolepis, while the one present in Ganga Brahmaputra River system is Tor putitora.

The statement by Mirza (2004) has led to confusion among the researchers in Pakistan as some named mahseer in the water bodies of Pakistan as Tor putitora (Ahmad, 1963; Rafique and Javed, 2002; Khan et al., 2008; Latif et al., 2016), while others identified it as Tor macrolepis (Mirza, 1973; Mirza et al., 2006; Saeed et al., 2013; Hasan et al., 2013; Yousafzai et al., 2013; Altaf et al., 2015). Taxonomic ambiguities have been posing problems for conservation of mahseer (Pinder et al., 2018). For the improvement of wild populations of Mahseer conservation strategies like protection of habitat and artificial propagation are necessary but it would be possible once the taxonomic ambiguities are settled (Morrison et al., 2009).
Keeping in view the lack of recent data regarding the diversity of mahseer in Indus river system, the present study was designed to i) document the diversity and distribution of the Mahseer in Pakistan, and ii) look for morphological evidence as stated by Mirza (2004) regarding presence of Tor putitora or Tor macrolepis in the Indus riverine system of Pakistan.

\section{Methodology}

\subsection{Riverine System of Pakistan}

Among freshwater reservoirs, Pakistan has rivers and many small and large tributaries which are collectively called Indus River system (Figure 1). The Indus River system is located on an area of about 1.12 million $\mathrm{Km}^{2}$, in which Pakistan occupies 47 percent, India 39 percent, China 8 percent and Afghanistan 6 percent (FAO, 2011). Glaciers cover $13 \%$ of the mountains in upper Indus basin (Shakir et al., 2010) and the water flow in River Indus is affected by the precipitation, temperature and solar radiations (Khan, 2001). About 60 to 70 percent of the total precipitation in Pakistan takes place in monsoon season from July to September and affects the river's flow (Salma and Rehman, 2012). River Indus is the backbone of riverine system in India and Pakistan, originating in Tibet from Kailash range, flowing westward falling into Arabian Sea and is about $3180 \mathrm{Km}$ in length and covers a drainage area of $945345 \mathrm{~km} 2$. Indus River system consists of 27 tributaries and seven main Rivers; Gomal River, Zhob River, Kurram River and Swat River originate in Pakistan.

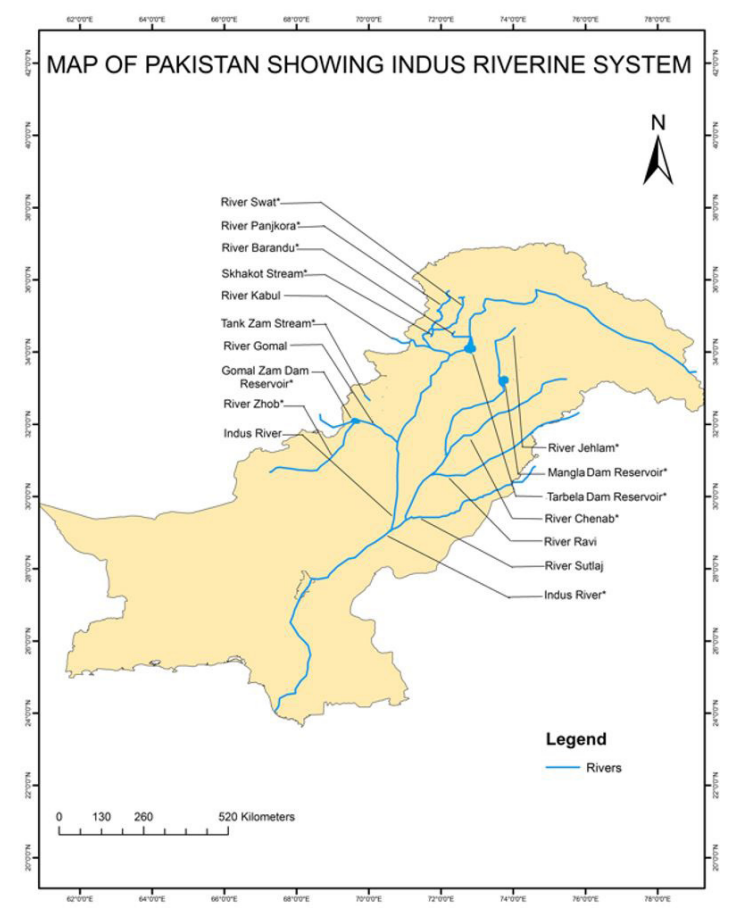

Figure 1. Map showing the Riverine System in Pakistan with collection points marked with *. 
Chenab, Ravi, Sutlej, Jhelum and Beas flows from India toward Pakistan and one River Kabul flows from Afghanistan to Pakistan. Pakistan has a well-established canal system covering about 780,000 hectares area including 9.7\% wetland in which $73 \%$ is fresh water and $27 \%$ is coastal wetland (Altaf et al., 2014).

\subsection{Collection, preservation and identification of specimen}

As golden mahseer (Tor putitora) is included in the IUCN red list of Endangered species so samples were collected from normal catch of the fishermen to avoid overfishing. Specimens were collected from River Swat (SWA), Chakdara (CHAK), River Panjkora (PAN), River Barandu (BAR), Terbela Dam Reservoir (TER), Skhakot (SKH), River Jehlum (JEH), River Chanab (CHAN), Gomal Zam Dam (GOM) and tributaries (Tank-Zam stream) of River Gomal and River Zhob (ZHOB) at regular intervals.

A total of 12 morphometric measurements (Costa et al., 2003) i.e. Total length (TL), Standard length (SL), Pre dorsal length (PRDL), Post dorsal length (PSDL), Head length(HL), Head height (HH), Body depth (BD), Rostral barbel length $(\mathrm{RBL})$, Maxillary barbel length (MBL), Eye diameter (ED) and both eye/interorbital distance (BED) and nine meristic counts i.e. dorsal spine, pectoral spine, pelvic spine, anal spine, caudal rays, lateral line scales (LLS), pre dorsal scales, above lateral line scales on the base of dorsal fin (ALLS) and below lateral line scales on the base of dorsal fin (BLLS) were counted . All morphometric characters were measured to the nearest centimeter with the accuracy of $1 \mathrm{~mm}$. Collected specimens were preserved in 90\% alcohol and transported to Department of Zoology, University of Peshawar, Pakistan. The specimens were tagged, and relevant information was documented. The specimens were identified using keys provided in Jayaram (1981) and Talwar and Jhingran (1991).

\subsection{Statistical analyses}

Ratios of various morphological characters were calculated in relation to TL, SL and HL. Means and standard deviations were calculated. t-test was conducted to compare the interspecific and intraspecific morphological ratios at $P<0.05$. Correlation coefficient " $r$ " of overall collection as well as each population was calculated for each morphological measurement in relation to TL, SL and HL. Statistical analysis was carried out using SPSS (IBM Corp.) v 22.0

\section{Results}

In this study we collected 109 specimens of mahseer from 10 different water bodies of Pakistan and reported two species belonging to two different genera of mahseer i.e. Tor and Naziritor. Tor putitora was collected from all water bodies surveyed during the current study. It was having dark grey dorsum and light silvery grey dorsoventral surface with golden yellow fins and silvery white abdomen (Figure 2). The fish was having keeled head with head length less than, equal to or greater than the body depth. All specimens were having fleshy lips and were not showing any differentiation among the lower lip structure (Figure 3). Tor putitora have 24 to 28 LLS, 9 pre dorsal scales, 3.5 ALLS and 2.5 BLLS (Table 1). Mean TL of Tor putitora was $24.49 \mathrm{~cm}$ having a range of 12.24 to $41.36 \mathrm{~cm}$ with minimum length recorded from Skhakot and maximum from Jehlum. The mean weight was observed to be 207.1 gm having a range of 21.2 to $527 \mathrm{gm}$ with minimum weight recorded from Skhakot and maximum from Jehlum (Table 2). Ratios of various morphometric measurements in percentage were calculated in relation to TL, SL and HL (Table 3 ). The pre dorsal length was found to be more than post dorsal length and HL was more than BD and $\mathrm{HH}$. The ED was more than BED, the maxillary barbel were shorter than rostral barbel. Overall, the body depth was less than head length (98.2\%) but in two populations, river Chenab (112.68) and river Jhelum (113.37) the body depth was more than head length (Table 3).

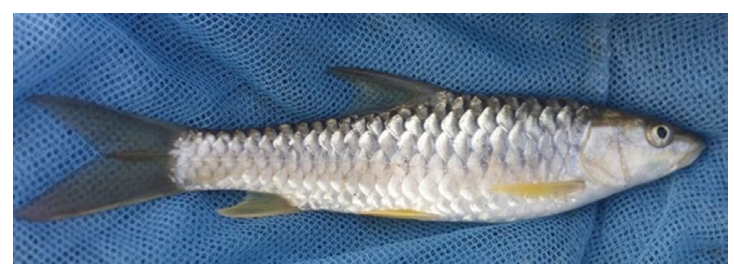

Figure 2. Lateral view of Tor putitora collected during the study.

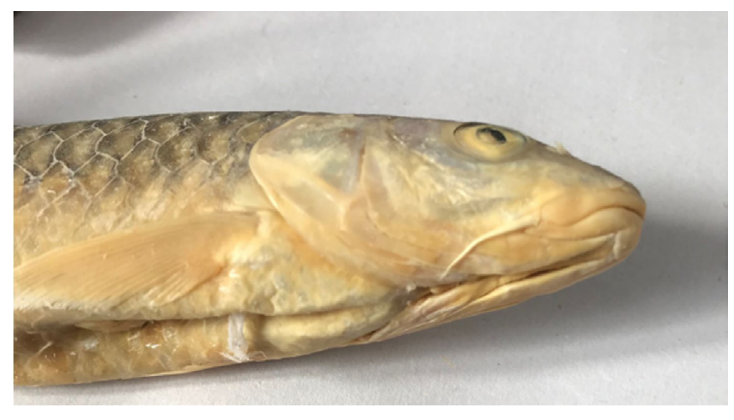

Figure 3. Mental lobe of Tor putitora collected during the study.

Table 1. Meristic counts of the two mahseer species collected from water bodies of Pakistan.

\begin{tabular}{lcc}
\hline \multicolumn{1}{c}{ Parameter } & Tor putitora & $\begin{array}{c}\text { Naziritor } \\
\text { zhobensis }\end{array}$ \\
\hline Dorsal Spine & $1 / 9=10$ & $1 / 9=10$ \\
Pectoral Spine & $14-17$ & $15-18$ \\
Pelvic Spine & $1 / 8=9$ & $1 / 8=9$ \\
Anal Spine & $2 / 5=7$ & $2 / 5=7$ \\
Caudal Spine & 19 & $19-21$ \\
LLS & $24-28$ & $32-37$ \\
Pre dorsal Scale & 9 & $13-14$ \\
ALLS & 3.5 & 4.5 \\
BLLS & 2.5 & 3.5 \\
\hline
\end{tabular}


Naziritor zhobensis generally known as Zhobi mahseer has a grey dorsal and light grey dorsoventral surface (Figure 4) with slight yellow fins and silver white abdomen. The fish has broad snake like head and head length was almost greater than body depth (Figure 5). Specimens have 32 to 37 LLS, 13 to 14 pre dorsal scales, 4.5 ALLS and 3.5 BLLS (Table 1). The fish was having a mean TL of $15.65 \mathrm{~cm}$ with a range of 10 to $27 \mathrm{~cm}$, while the mean total weight was $59 \mathrm{gm}$ with a range of 38 to $135 \mathrm{gm}$. Ratios of various morphometric measurements in percentage were calculated in relation to TL, SL and HL (Table 3). The pre dorsal length was more than post dorsal length, HL was more than BD and $\mathrm{HH}$ and the ED was more than BED. The maxillary barbel were shorter than rostral barbel.

Subjecting the morphometric ratios of different populations of Tor putitora and Naziritor zhobensis to

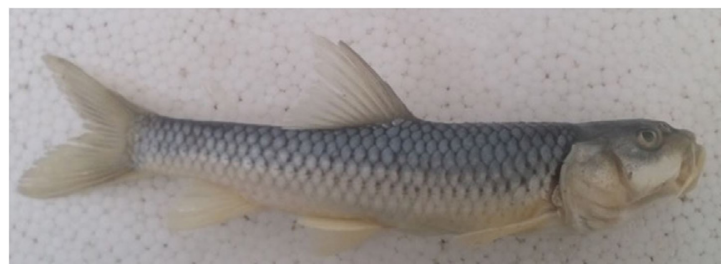

Figure 4. Lateral view of Naziritor zhobensis collected during the study.

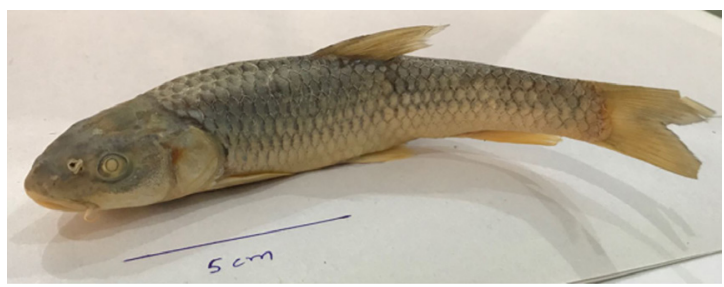

Figure 5. Dorsolateral view of Naziritor zhobensis collected during the study. statistical analysis (t-test), it has been observed that in Tor putitora, though SL/TL of Gomal Zam population was less than other populations, but this relation was significant $(P<0.05)$ with river Swat, Jhelum and Chenab populations only. No difference $(P>0.05)$ has been observed in the ratios of PRDL and PSDL to SL and TL among various populations. Remaining ratios varied among various populations (Table 3$)$. HL/TL was significantly larger $(P<0.05)$ in river Barandu and Skhakot population as compared to Jhelum and Chenab populations wile HL/SL was significantly small for Jhelum as compared to other population and significant difference has been observed between Skahkot and Chenab population $(P<0.05)$. In $\mathrm{BD} / \mathrm{TL}$ significant difference has been observed between Jhelum and Tarbela, Chenab and Terbela, while for BD/SL only river Jhelum population differed significantly from all other populations except Chenab. BD/HL ratios form two groups, one was Jhelum and Chenab having similar ratios while second group composed of Swat, Chakdara, Panjkora, Barandu, Skhakot, Tarbela and Gomal Zam Dam reservoir. Remaining morphometric ratios were not showing relationship that can distinguish specific groups among different population (Table 2). When Naziritor zhobensis (ZHOB) morphometric ratios were compared with Tor putitora SL/TL, PRDL and PSDL with TL and SL, BED/HL and RBL/HL were similar while remaining measurements differed significantly $(P<0.05)$ from Tor putitora.

In all the 10 locations individual morphometric parameters were tested to know the correlation between different body parts. Along with each individual population the overall (99 specimens) collection was also tested for correlation coefficient " $\mathrm{r}$ ". Among the nine population of Tor putitora and one Naziritor zhobensis population a weak $(\mathrm{r}<0.6)$, moderate $(\mathrm{r}=0.6-0.85)$ and high $(\mathrm{r}>0.85)$ level of correlation has been observed (table 4). SL, PRDL, PSDL, HL, BD with TL and PRDL with SL showed a high positive correlation while HH with TL, PSDL, HL, BD, $\mathrm{HH}$ with SL and $\mathrm{HH}, \mathrm{BD}$ with $\mathrm{HL}$ showed both moderate

Table 2. The morphometric of Tor putitora and Naziritor zhobensis collected from various Rivers in Pakistan.

\begin{tabular}{lcccccccccc}
\hline \multicolumn{1}{c}{ Parameters/ Areas } & SWA & CHAK & PAN & BAR & SKH & TER & JEH & CHEN & GOM & ZHOB \\
\hline Total length & 16.98 & 16.9 & 16.36 & 18.66 & 12.24 & 36.77 & 41.36 & 34.46 & 24.9 & 15.65 \\
Standard length & 14.11 & 13.78 & 13.48 & 15.27 & 9.84 & 30.04 & 34.96 & 28.80 & 19.8 & 12.8 \\
Lateral line Scales & 26.7 & 27.3 & 26.4 & 25.22 & 27.14 & 26.45 & 26.6 & 27.66 & 25.9 & 34 \\
Pre dorsal length & 7.01 & 6.95 & 6.83 & 7.588 & 4.88 & 15.33 & 17.28 & 14.23 & 9.93 & 6.43 \\
Post dorsal length & 10.31 & 10.29 & 9.8 & 11.24 & 7.41 & 22.78 & 25.2 & 21.05 & 15.27 & 9.11 \\
Head Length & 3.6 & 3.6 & 3.47 & 4.12 & 2.67 & 7.58 & 7.96 & 6.81 & 5.23 & 3.57 \\
Body depth & 3.49 & 3.44 & 3.27 & 3.91 & 2.48 & 7.05 & 8.98 & 7.74 & 4.95 & 2.64 \\
Head height & 2.35 & 2.45 & 2.31 & 2.77 & 1.82 & 4.79 & 5.98 & 4.30 & 3.23 & 2 \\
Eye diameter & 0.75 & 0.8 & 0.9 & 1.01 & 0.6 & 1.64 & 1.58 & 1.31 & 1.05 & 0.67 \\
Both Eye distance & 1.26 & 1.17 & 1.11 & 1.27 & 0.88 & 2.37 & 2.92 & 2.15 & 1.49 & 1.14 \\
Maxillary barbel length & 0.75 & 0.87 & 0.82 & 1 & 0.67 & 2.18 & 2.06 & 1.65 & 1.33 & 0.86 \\
Rostral barbel length & 1 & 1.05 & 0.97 & 1.2 & 0.84 & 2.37 & 2.02 & 1.875 & 1.45 & 1.03 \\
\hline
\end{tabular}

SWA (River Swat), CHAK (River at Chakdara), PAN (River Panjkora), BAR (River Barandu), SKH (Stream in Skhakot), TER (Terbela Dam Reservoir), JEH (River Jehlum), CHEN (River Chenab), GOM (Gomal-Zam Dam) 
Table 3. Comparison of mean of Morphometric ratios (\%) of specimens collected in all localities with statistically significant localities shown with similar letter.

\begin{tabular}{|c|c|c|c|c|c|c|c|c|c|c|c|}
\hline & Localities & SWA & CHAK & PAN & BAR & SKH & TER & JEH & CHAN & GOM & N. zhobensis \\
\hline & Parameters & A & B & C & D & $\mathbf{E}$ & $\mathbf{F}$ & G & H & I & J \\
\hline 1 & $\mathrm{SL} / \mathrm{TL}$ & $82.99^{1}$ & 81.43 & 81.6 & 81.53 & 80.09 & 81.71 & 82.73 & $83.5^{1}$ & $79.51 \mathrm{AH}$ & 82.07 \\
\hline 2 & PRDL/ TL & 41.33 & 41.06 & 41.8 & 40.71 & 40.68 & 41.66 & 40.64 & 41.3 & 39.87 & 41.47 \\
\hline 3 & PSDL/ TL & 60.61 & 60.96 & 60 & 60.24 & 61.25 & $61.9^{\mathrm{J}}$ & $61.97 \mathrm{~J}$ & 61.2 & 61.54 & $58.73 \mathrm{FG}$ \\
\hline 4 & $\mathrm{HL} / \mathrm{TL}$ & $21.2^{\mathrm{J}}$ & 21.28 & $21.2^{\mathrm{J}}$ & $22.17^{\mathrm{GH}}$ & $22.4^{\mathrm{GH}}$ & $20.68^{\mathrm{J}}$ & 20.06 DEJ & $19.8^{\mathrm{DEJ}}$ & $21.06^{\mathrm{J}}$ & 23.01 AFGHI \\
\hline 5 & $\mathrm{BD} / \mathrm{TL}$ & $20.63^{J}$ & $20.37 \mathrm{~J}$ & $20^{\mathrm{HJ}}$ & $21.08^{\mathrm{J}}$ & $20.77 \mathrm{~J}$ & $19.22 \mathrm{GHJ}$ & $21.48^{\mathrm{FJ}}$ & $22.4^{\mathrm{CFIJ}}$ & $19.93 \mathrm{HJ}$ & 16.98 ALL \\
\hline 6 & $\mathrm{HH} / \mathrm{TL}$ & 13.84 & $14.48^{\mathrm{H}}$ & $14.1^{\mathrm{H}}$ & $14.91^{\mathrm{FHIJ}}$ & $15.24^{\mathrm{FHIJ}}$ & $13.04^{\mathrm{DE}}$ & $14.44^{\mathrm{H}}$ & $12.5^{\text {BCDEG }}$ & $12.94^{\mathrm{DE}}$ & $12.96^{\mathrm{DE}}$ \\
\hline 7 & $\mathrm{ED} / \mathrm{TL}$ & $4.459^{\text {в }}$ & $4.76^{\mathrm{AGH}}$ & $5.52 \mathrm{AFGHJ}$ & $5.311 \mathrm{GHI}$ & $5.301 \mathrm{GH}$ & $4.479^{c}$ & $3.663 \mathrm{BCDE}$ & $3.844^{\mathrm{BCDE}}$ & $4.31^{\mathrm{CDE}}$ & $4.456^{c}$ \\
\hline 8 & $\mathrm{BED} / \mathrm{TL}$ & $7.42^{\mathrm{FHI}}$ & 6.968 & 6.78 & 6.833 & 7.34 I & $6.448^{A}$ & $7.102^{1}$ & $6.26^{\mathrm{AEJ}}$ & $5.98 \mathrm{AEGJ}$ & $7.284^{\mathrm{HI}}$ \\
\hline 9 & $\mathrm{MBL} / \mathrm{TL}$ & $4.4^{\text {DEFIJ }}$ & $5.133^{\mathrm{F}}$ & $5.04^{\mathrm{F}}$ & $5.358^{\mathrm{A}}$ & $5.522^{\mathrm{A}}$ & $5.95 \mathrm{ABCGH}$ & $5.175^{\mathrm{F}}$ & $4.78^{\mathrm{E}}$ & $5.307^{A}$ & $5.542^{\mathrm{AH}}$ \\
\hline 10 & $\mathrm{RBL} / \mathrm{TL}$ & $5.869^{\mathrm{E}}$ & 6.228 & $5.95^{\mathrm{E}}$ & $6.472{ }^{\mathrm{H}}$ & 7.06 ACGHI & $6.46^{\mathrm{GH}}$ & $5.688^{\mathrm{EFJ}}$ & $5.44^{\mathrm{DEFJ}}$ & 5.793 ㄹ & $6.638 \mathrm{GHI}$ \\
\hline 11 & PRDL/SL & 49.82 & 50.44 & 51.2 & 49.96 & 50.85 & 51 & 49.41 & 49.4 & 50.16 & 50.58 \\
\hline 12 & PSDL/SL & $73.06^{1}$ & 74.94 & 73.5 & 73.91 & $76.49 \mathrm{~J}$ & $75.7 \mathrm{~J}$ & $72.32^{1}$ & $73.2^{1}$ & $77.41 \mathrm{AGHJ}$ & 71.67 EFI \\
\hline 13 & $\mathrm{HL} / \mathrm{SL}$ & $25.55^{G}$ & $26.18^{G}$ & $26^{G}$ & $27.21^{\mathrm{G}}$ & $28.01 \mathrm{GH}$ & $25.31^{\mathrm{G}}$ & $19.03 \mathrm{ALL}$ & $23.7^{\mathrm{DEGJ}}$ & $26.49^{G}$ & $28.08 \mathrm{GH}$ \\
\hline 14 & $\mathrm{BD} / \mathrm{SL}$ & $24.89^{\mathrm{J}}$ & $25.07 \mathrm{~J}$ & $24.5^{\mathrm{J}}$ & $25.88^{\mathrm{J}}$ & $25.95^{\mathrm{J}}$ & $23.52^{\mathrm{J}}$ & 25.99 & $26.8^{\mathrm{J}}$ & $25.07^{\mathrm{J}}$ & 20.71 АBDEHI \\
\hline 15 & $\mathrm{HH} / \mathrm{SL}$ & $16.69^{\mathrm{G}}$ & $17.78 \mathrm{GH}$ & $17.3^{\mathrm{G}}$ & $18.3^{\mathrm{GH}}$ & $19.04^{\mathrm{FGHJ}}$ & $15.95^{\mathrm{E}}$ & $13.77 \mathrm{ABCDE}$ & $15^{\mathrm{BDE}}$ & 16.29 & $15.82^{\mathrm{E}}$ \\
\hline 16 & $\mathrm{ED} / \mathrm{SL}$ & $5.38^{\mathrm{CDE}}$ & $5.85^{\mathrm{GH}}$ & $6.76^{\mathrm{AFGHIJ}}$ & $6.521^{\mathrm{AGH}}$ & $6.638^{\mathrm{AGH}}$ & $5.486^{c}$ & $4.51^{\mathrm{BCDE}}$ & $4.6^{\mathrm{BCDE}}$ & 5.424 & $5.438^{\mathrm{E}}$ \\
\hline 17 & $\mathrm{BED} / \mathrm{SL}$ & $8.95 \mathrm{GH}$ & $8.562^{G}$ & $8.31^{\mathrm{G}}$ & $8.393^{G}$ & $9.174 \mathrm{GHI}$ & 7.893 & 6.769 АВCDEJ & $7.49 \mathrm{AE}$ & $7.52^{\mathrm{E}}$ & $8.896^{G}$ \\
\hline 18 & $\mathrm{MBL} / \mathrm{SL}$ & 5.3 DEFIJ & $6.302^{\mathrm{G}}$ & 6.17 FG & $6.578^{A G}$ & 6.899 AGH & $7.28^{\mathrm{ACGH}}$ & 4.89 BCDEFIJ & 5.72 EFJ & $6.676^{A G}$ & 6.749 AGH \\
\hline 19 & $\mathrm{RBL} / \mathrm{SL}$ & $7.08 \mathrm{EGJ}$ & 7.65 EGH & 7.29 EG & $7.946 \mathrm{GH}$ & $8.82 \mathrm{ABCGHI}$ & $7.906 \mathrm{GH}$ & 5.213 ALL & $6.51^{\mathrm{BDEFGJ}}$ & $7.286^{\text {EG }}$ & 8.089 AGH \\
\hline 20 & $\mathrm{HH} / \mathrm{HL}$ & $65.33^{\mathrm{J}}$ & $68.2^{\mathrm{J}}$ & $66.7^{\mathrm{J}}$ & $68.16^{J}$ & $68.13 \mathrm{~J}$ & 63.09 & 71.82 I & 63.4 & $61.59^{G}$ & 56.29 ABCDEG \\
\hline 21 & $\mathrm{ED} / \mathrm{HL}$ & $21.05^{c}$ & 22.4 & $26^{\mathrm{AGII}}$ & $24.25^{\mathrm{J}}$ & 23.43 & $21.7^{\mathrm{HJ}}$ & 25.28 & $19.4^{\mathrm{CDG}}$ & $20.47^{c}$ & $19.37^{\mathrm{CG}}$ \\
\hline 22 & $\mathrm{BED} / \mathrm{HL}$ & $35.01^{1}$ & $32.84^{1}$ & 32 & $30.77^{\mathrm{G}}$ & 32.86 & $31.23^{G}$ & $35.5^{\mathrm{DFI}}$ & 31.6 & $28.4^{\mathrm{AG}}$ & 31.68 \\
\hline 23 & $\mathrm{MBL} / \mathrm{HL}$ & $20.74^{1}$ & $24.22^{1}$ & $23.8^{1}$ & $24.49^{1}$ & $24.76^{1}$ & $28.76^{1}$ & $25.63^{I}$ & $24.2^{\mathrm{I}}$ & 25.19 ALL & $24.03^{1}$ \\
\hline 24 & $\mathrm{RBL} / \mathrm{HL}$ & 27.7 & 29.39 & 28.1 & 29.52 & 31.58 & 31.26 & 28.4 & 27.5 & 27.52 & 28.81 \\
\hline 25 & $\mathrm{BD} / \mathrm{HL}$ & $97.0 \mathrm{GHJ}$ & $95.73 \mathrm{GHJ}$ & $94.2^{\mathrm{GHJ}}$ & $95.15 \mathrm{GHJ}$ & $92.8^{\mathrm{GHJ}}$ & $93.01 \mathrm{GHJ}$ & $108.2^{\mathrm{ALL}}$ & $113^{\mathrm{ALL}}$ & $94.61 \mathrm{GHJ}$ & 77.19 ALL \\
\hline
\end{tabular}

SWA (River Swat), CHAK (River at Chakdara), PAN (River Panjkora), BAR (River Barandu), SKH (Stream in Skhakot), TER (Terbela Dam Reservoir), JEH (River Jehlum), CHAN (River Chenab), GOM (Gomal-Zam Dam)

and high positive correlation among these body parts. Remaining relationships among various body parts showed weak, moderate and high positive correlation. All these correlations were positive, thus showing an isometric growth of various body parts in both these species of mahseer in Pakistan.

\section{Discussion}

Current study reports the presence of two mahseer species in semi cold water bodies of Indus riverine system (Pakistan). Tor putitora was reported from all surveyed water bodies while Naziriotr zhobensis was reported from Zhob River and tributaries of Gomal River only. Various studies have previously reported Tor putitora along with Tor mosal and Tor tor from Pakistan. Mirza and Javed (1985) described Tor mosal and Tor tor as same species and concluded the presence of Tor putitora, Tor tor and Naziritor zhobensis from Pakistan based on morphological characters. Since then, only Tor putitora has been reported from Pakistan. The presence of Tor tor also known as deep bodied may have been a case of mis identification as both species have same head morphology and meristic counts but differ in body shape and body colouration. Naziritor zhobensis, not reported since its first record (Mirza, 1967) has been collected in the present survey showing that Zhobi mahseer is still extant and exist in the water bodies of west Pakistan.

The Himalayan Rivers and tributaries are permanent habitat of Tor putitora (Pandit and Grumbine, 2012) and is not only restricted to Indus and the bio geographical zone of Ganga and Brahamputra River system but is widely distributed in Afghanistan, India, Bangladesh, Bhutan, Nepal, Mayanmar and Pakistan (Joshi et al., 2018). As stated above, all the Rivers in Pakistan are connected 
Table 4. Population wise correlation among various morphometric measurements of Tor Putitora and Naziritor zhobensi.

\begin{tabular}{|c|c|c|c|c|c|c|c|c|c|c|c|}
\hline \multicolumn{2}{|c|}{ Localities } & \multirow{2}{*}{ SWA } & \multirow{2}{*}{ CHK } & \multirow{2}{*}{ PAN } & \multirow{2}{*}{ BAR } & \multirow{2}{*}{ SKH } & \multirow{2}{*}{ TER } & \multirow{2}{*}{ JEH } & \multirow{2}{*}{ CHAN } & \multirow{2}{*}{ GOM } & \multirow{2}{*}{ N. zhobensis } \\
\hline & Parameters & & & & & & & & & & \\
\hline 1 & SL and TL & 0.989 & 0.985 & 0.884 & 1 & 0.999 & 0.989 & 0.997 & 0.978 & 0.997 & 0.993 \\
\hline 2 & PRDL and TL & 0.993 & 0.979 & 0.877 & 0.994 & 0.986 & 0.988 & 0.994 & 0.967 & 0.868 & 0.995 \\
\hline 3 & PSDL and TL & 0.989 & 0.993 & 0.93 & 0.993 & 0.994 & 0.984 & 0.989 & 0.957 & 0.975 & 0.995 \\
\hline 4 & HL and TL & 0.989 & 0.937 & 0.856 & 0.916 & 0.992 & 0.948 & 0.967 & 0.921 & 0.993 & 0.989 \\
\hline 5 & $\mathrm{BD}$ and $\mathrm{TL}$ & 0.971 & 0.874 & 0.898 & 0.896 & 0.989 & 0.86 & 0.94 & 0.871 & 0.939 & 0.91 \\
\hline 6 & $\mathrm{HH}$ and $\mathrm{TL}$ & 0.933 & 0.916 & 0.947 & 0.875 & 0.992 & 0.859 & 0.972 & 0.707 & 0.837 & 0.956 \\
\hline 7 & ED and TL & 0.681 & 0.604 & 0.440 & 0.710 & 0.649 & 0.486 & 0.975 & 0.324 & 0.781 & 0.82 \\
\hline 8 & BED and TL & 0.845 & 0.858 & 0.877 & 0.224 & 0.995 & 0.818 & 0.98 & 0.578 & 0.984 & 0.977 \\
\hline 9 & MBL and TL & 0.81 & 0.837 & 0.117 & 0.922 & 0.994 & 0.717 & 0.871 & 0.862 & 0.965 & 0.883 \\
\hline 10 & RBL and TL & 0.85 & 0.852 & 0.472 & 0.937 & 0.989 & 0.831 & 0.835 & 0.886 & 0.979 & 0.919 \\
\hline 11 & PRDL and SL & 0.994 & 0.981 & 0.976 & 0.995 & 0.985 & 0.981 & 0.991 & 0.973 & 0.87 & 0.994 \\
\hline 12 & PSDL and SL & 0.983 & 0.971 & 0.844 & 0.993 & 0.995 & 0.979 & 0.992 & 0.965 & 0.977 & 0.988 \\
\hline 13 & HL and SL & 0.989 & 0.878 & 0.827 & 0.914 & 0.99 & 0.97 & 0.971 & 0.938 & 0.994 & 0.985 \\
\hline 14 & $\mathrm{BD}$ and $\mathrm{SL}$ & 0.952 & 0.81 & 0.889 & 0.893 & 0.99 & 0.846 & 0.957 & 0.909 & 0.933 & 0.914 \\
\hline 15 & $\mathrm{HH}$ and SL & 0.926 & 0.915 & 0.918 & 0.872 & 0.992 & 0.855 & 0.98 & 0.786 & 0.823 & 0.95 \\
\hline 16 & ED and SL & 0.681 & 0.569 & 0.493 & 0.699 & 0.633 & 0.444 & 0.982 & 0.343 & 0.787 & 0.772 \\
\hline 17 & BED and SL & 0.851 & 0.883 & 0.882 & 0.224 & 0.993 & 0.813 & 0.987 & 0.619 & 0.989 & 0.977 \\
\hline 18 & MBL and SL & 0.825 & 0.857 & 0.254 & 0.915 & 0.993 & 0.734 & 0.894 & 0.812 & 0.961 & 0.9 \\
\hline 19 & RBL and SL & 0.829 & 0.858 & 0.526 & 0.933 & 0.993 & 0.833 & 0.839 & 0.843 & 0.981 & 0.934 \\
\hline 20 & $\mathrm{BD}$ and $\mathrm{HL}$ & 0.966 & 0.956 & 0.923 & 0.98 & 0.992 & 0.784 & 0.958 & 0.906 & 0.94 & 0.905 \\
\hline 21 & $\mathrm{HH}$ and $\mathrm{HL}$ & 0.925 & 0.855 & 0.918 & 0.765 & 0.992 & 0.88 & 0.976 & 0.832 & 0.794 & 0.968 \\
\hline 22 & ED and HL & 0.675 & 0.589 & 0.609 & .0731 & 0.717 & 0.377 & 0.975 & 0.389 & 0.767 & 0.756 \\
\hline 23 & BED and HL & 0.872 & 0.804 & 0.869 & 0.199 & 0.99 & 0.798 & 0.98 & 0.607 & 0.981 & 0.986 \\
\hline 24 & MBL and HL & 0.823 & 0.72 & 0.207 & 0.832 & 0.982 & 0.764 & 0.873 & 0.857 & 0.965 & 0.925 \\
\hline 25 & RBL and HL & 0.84 & 0.726 & 0.531 & 0.874 & 0.97 & 0.847 & 0.838 & 0.825 & 0.975 & 0.953 \\
\hline
\end{tabular}

with each other through the Indus Riverine system. Tor putitora being a migratory fish (Malik and Negi, 2007) migrate seasonally for breeding and feeding between these rivers. The main Rivers like Indus River which originates in Tibet; China enters Jammu and Kashmir and then flow in the Indus plain of Pakistan, have a rich population of Tor putitora (Sarkar et al., 2015). Tor putitora collected from all nine water bodies of Pakistan in present study have same Morphological characteristics. River Chenab in India receives Jhajjar Stream, Dansar stream and River Tawi before entering Pakistan and it then joins Indus River system. Tor putitora has been reported from all these tributaries of River Chenab (Sharma et al., 2015). The Seer Stream and Pong Reservoir of Himachal Pardesh being part of River Beas also has population of Tor putitora (Arora and Julka, 2013). In majority of the above discussed stream which enters from India to Pakistan Tor putitora has been reported which supports the statement of present study that Mahseer reported from all the rivers of Indus river system is Tor putitora.
Comparing the ratios of Tor putitora in current study, it has been observed that they are within the range of ratios reported by other studies done on the same species. Larger caudal fin in Gomal Zam dam population might be due to swift flow of rocky stream flowing to the Dam as stated by Langerhans (2008) that the water flow has effect upon body shape due to adaptations for swimming in fast flowing water. Fish which inhabit the fast-flowing water bodies have elongated and fusiform body shape as compared to the fish residing slow flowing water bodies (Drinan et al., 2012). The standard, pre and post dorsal lengths reported in current study has been found to be in the same range as reported in golden mahseer from Attock area of Punjab province in Pakistan (Pervaiz et al., 2012), from three localities in Indian occupied Jammu and Kashmir (Sharma et al., 2015) and from Indian Rivers and streams (Bhatt and Pandit, 2016).

Based on the characters of head length greater than body depth for Indus golden Mahseer Pervaiz et al. (2012) was in agreement with Mirza and Javed (1986), that 
mahseer having head length greater than body depth is Tor macrolepis. Specimens collected in this study have body depth (\%BD/SL) within the same range (23.48-26.78) as that reported by Pervaiz et al., (2012) that reported body depth to be $22.58-28.53 \%$ of standard length. Studies conducted on Tor putitora in India reported body depth of 24.52-29.01 (Dasgupta, 1991), 25.04-27.68 (Sharma et al., 2015) and 24.58-25.75 (Langer et al., 2013), which lies within the same range as reported by our study except for Tor putitora collected from Tarbela Dam reservoir which was having more fusiform body but this variation in body depth was found to be non-significant among fish collected from different water bodies in this study. This showed that the body depth reported in our study has been similar to the body depth reported for Tor putitora from other parts of the South Asia.

The head length in relation to body depth (\%BD/HL) of Tor putitora has shown that the head length was observed to be more than, equal to as well as less than body depth in specimens collected in our study (body depth ranged from $79.63-124.1 \%$ of head length, mean $=97.87$ ) which is in agreement with the statement of Sarma et al., (2014, 2015). Sharma et al. (2015) recorded a mean body depth to head length ratio of $91.1 \%$ in Tor putitora collected from Indian occupied Kashmir and Bhatt et al. (1998) also reported a mean of $83.7 \%$ in Tor putitora from Indian Rivers and streams. Though Pervaiz et al. (2012) named the Indus golden mahseer as Tor macrolepis on the character of head length greater than body depth but in their own collection they reported a maximum value of $109 \%$ (66.07-109\% mean $90.82 \%, \mathrm{n}=118, \mathrm{TL}=12.32-15.86 \mathrm{~cm}$ ).

Observations of current study has been found to be in agreement with Sharma et al. (2015) and Bhatt and Pandit (2016) that head length could be greater than body depth except in the populations of River Jhelum and Chenab where head length is less than body depth. The heads of Jhelum and Chenab population were shorter, but their heads were deeper as compared to other populations which may be due to the slow flowing nature of the river Jhelum. It has been observed that the mean weight of stomach of a fish species in a reservoir or deep and slow flowing water body is higher than the fish specimen residing in the fast-flowing river (Agostinho et al., 1999), which could be the probable reason for an increase in body depth in comparison to head length in the specimens of Rivers Jhelum and Chenab. The ecology of a water bodies might exhibit biotic and abiotic variability (Goulding et al., 1988), which cause phenotypic plasticity in morphology as noted in Carassius carassius in the presence or absence of their predator and in Chum salmon (Onchorhynchus keta) in response of temperature variations (Beacham, 1990). Tor putitora collected in the present study from all localities possess fleshy lips and have not shown any differentiation among lower lip structure which is in agreement with Khare et al. (2014). Heckel (1838) described these fleshy lips of Tor macrolepis as hypertrophied lips but Khare et al. (2014) in a study comparing different mahseer species with Tor macrolepis of Indus Riverine system stated it as a thick lip morphotype of Tor putitora.

Ichthyologist like (Hora, 1939; Sen and Jayaram, 1982; Mirza and Javed, 1986; Menon, 1992; Talwar and Jhingran,
1991) stated that Tor putitora can only be distinguished from other Tor on the basis of its head length which is greater than body depth but recently Sarma et al. (2014, 2015) have reported that the head length of Tor putitora could be equal, greater or less than the body depth. The result of present study concludes that in the tested populations of Tor putitora collected from Swat, Chakdara, Panjkora, Barandu, Terbela, Skhakot and Gomal the head length is greater than body depth but in the populations of River Jhelum and River Chenab the head length is less than body depth, which was also reported by Pervaiz et al. (2012) in two populations of their collection from Attock region of Punjab province in Pakistan and named them as Tor macrolepis, although in two samples of Pervaiz et al. (2012) the head length was less than body depth going against the argument of Mirza (2004) regarding head length greater than body depth for Tor macrolepis.

Morphological diversity within a fish species could be due to distribution of the species on a vast geographical scale having diverse environmental conditions and fluctuations in rivers (Baker and Foster, 2002). The environmental conditions of rivers along with the genotype influence the phenotype of the fish (Schlichting, 1986) and results in phenotypic plasticity (Scheiner, 1993). The morphological identification using morphometric and meristic counts has been the most widely used method for species taxonomy and evolution (Schreck and Moyle, 1990), but current species concept is based on genetic, ecological, behavioral and morphological characters. In a study conducted on the effect of genetics and environmental variation on the morphology of Pimelodella chagresi, a Neotropical Catfish Species, it has been observed that the structure of riverbed and turbidity of water influence the availability and quality of food which exert pressure on fish physiology and act as environmental factor (Moeser and Bermingham, 2005).

The diversity of fish community of a particular river also influences a species as interspecific competition for food and breeding ground may influence the species morphology. These environmental factors like water flow, quality, river extension and isolation may exert a pressure on the species to evolve morphologically for adaptation to environmental changes (Vidalis and Tsimenidis, 1996). These environmental changes and intraspecific phenotypic plasticity have been reported several times in fishes (Heins et al., 2004; Blanck and Lamouroux 2007). The specimens of Tor putitora collected in present study from different water bodies have shown some phenotypic variations i.e. the Head length and body depth ratios are different at Jhelum and Chenab as compared to the specimens of other water body. The specimens of Naziritor zhobensis have very clear differences with Tor putitora in count of lateral line scales, pre dorsal scales, above lateral line scales and broadness of head, however, Tor putitora collected from various water bodies have shown no such type of significant differences with each other so that to declare them a separate species and only minute phenotypic changes have been observed which could be due to environmental variation and might be a result of phenotypic plasticity. 
Fish are sensitive to environmental variations and shows a good response to overcome the environmental fluctuations (Karr et al., 1986). Due to wide range of distribution Tor putitora some time shows morphological differences, which could be due to environmental fluctuations like turbidity, temperature, depth, width and flow of water in different rivers. These environmental variations cause phenotypic plasticity that could be responsible for the taxonomic ambiguity of a fish status (Khare et al., 2014). But present study observed that due to wide geographical distribution, Tor putitora exist in variety of aquatic habitats that results in morphological variations due to phenotypic plasticity and as these morphological differences are not only observed in current study but also in studies conducted in India (Sharma et al., 2015; Bhatt and Pandit, 2016), though in Pakistan these differences have led to describing the golden Mahseer present in Indus river system as Tor macrolpis.

Based on the above discussion it could be concluded that Tor putitora in Pakistan has been misidentified as Tor macrolepis. This misidentification of Tor putitora in Pakistan as Tor macrolepis (Pervaiz et al., 2012; Hasan et al., 2013; Altaf et al., 2015) have risen concerns among conservationist regarding risk of production of hybrid (Avise, 2000). The correct identification is helpful for conservation of endangered species (Morrison et al., 2009), which is important because some researchers have focused on conservation and breeding of Tor putitora (Sarma et al., 2010). Morphological variations due to wide distribution and variety of environmental conditions could result in variation of head length, which may be equal, less or greater than body depth (Sarma et al., 2014, 2015). Researchers (Pervaiz et al., 2012) describing Tor putitora as Tor macrolepis have also reported head length to be equal, less or greater than body depth in their study. Either describing golden mahseer in Pakistan water bodies previously as Tor macrolepis has been a case of misidentification or Tor macrolepis could be a junior synonym of Tor putitora but it requires further investigation like molecular evidence. The second species of Mahseer present in Pakistan is Naziritor zhobensis, the Zhobi mahseer, which is endemic to Pakistan and exist in the river Zhob, river Gomal and tributaries feeding these two rivers and Gomal Zam Dam reservoir.

\section{References}

AGOSTINHO, A.A., MIRANDA, L.E., BINI, L.M., GOMES, L.C., THOMAZ, S.M. and SUZUKI, H.I. 1999. Patterns of colonization in Neotropical reservoirs, and prognoses on aging. In J. G. Tundisi and M. Straskraba, eds. Theoretical reservoir ecology and its applications. Leiden: Backhuys Publishers.

AHMAD, N., 1963. Freshwater fish fauna of West Pakistan. Agri Pakistan, vol. 14, pp. 77-82.

ALTAF, M., JAVID, A., KHAN, A.M., HUSSAIN, A., UMAIR, M. and ALI, Z., 2015. The status of fish diversity of river Chenab, Pakistan. The Journal of Animal and Plant Sciences, vol. 25, pp. 564-569.

ALTAF, M., JAVID, A. and UMAIR, M., 2014. Biodiversity of Ramsar sites in Pakistan. Republic of Moldova: LAP.

ARORA, R. and JULKA, J.P., 2013. Phenotype and genotype differentiation between two stocks of Tor putitora (Hamilton) population (pisces: cyprinidae) from Himachal Pradesh, India. International Journal of Plant, Animal and Environmental Sciences, vol. 3, pp. 31-41.

AVISE, J.C., 2000. Phylogeography, the history and formation of species. Cambridge, MA: Harvard Univ. Press. http://dx.doi. org/10.2307/j.ctv1nzfgj7.

BAKER, J.A. and FOSTER, S.A., 2002. Phenotypic plasticity for life history traits in a stream population of the threespined stickleback, Gasterosteus aculeatus L. Ecology Freshwater Fish, vol. 11, no. 1, pp. 20-29. http://dx.doi.org/10.1034/j.16000633.2002.110104.X.

BEACHAM, T.D., 1990. A genetic analysis of meristic and morphometric variation in chum salmon (Oncorhynchus keta) at three different temperatures. Canadian Journal of Zoology, vol. 68, no. 2, pp. 225-229. http://dx.doi.org/10.1139/z90-033.

BHATT, J.P., NAUTIYAL, P. and SINGH, H.R., 1998. Comparative study of morphometric characters of Himalayan mahseer Tor putitora (Ham.) between Ganga and Gobindsagar reservoir stocks. Indian Journal of Fisheries, vol. 45, pp. 85-87.

BHATT, J.P. and PANDIT, M.K., 2016. Endangered Golden mahseer Tor putitora Hamilton: a review of natural history. Reviews in Fish Biology and Fisheries, vol. 26, no. 1, pp. 25-38. http://dx.doi. org/10.1007/s11160-015-9409-7.

BLANCK, A. and LAMOUROUX, N., 2007. Large-scale intraspecific variation in life-history traits of European freshwater fish. Journal of Biogeography, vol. 34, no. 5, pp. 862-875. http:// dx.doi.org/10.1111/j.1365-2699.2006.01654.x.

CHATTA, A.M. and AYUB, M., 2010. Growth performance of hatchery reared Golden mahseer (Tor macrolepis) at Sialkot, Pakistan. Biologia, vol. 56, pp. 1-8.

COSTA, J. L., ALMEIDA, P. R., COSTA and M. J., 2003. A morphometric and meristic investigation of Lusitanian toadfish Halobatrachus didactylus (Bloch and Schneider, 1801): evidence of population fragmentation on Portuguese coast. Scientia Marina, vol. 67, pp. 219-231.

DASGUPTA, M., 1991. Biometry of the mahseer, Tor putitora(Hamilton) collected from Garo Hills, Meghalaya. Indian Journal of Fisheries, vol. 38, pp. 129-131.

DESAI, V.R., 2003. Synopsis of biological data on the tor mahseer Tor tor (Hamilton, 1822). Rome: FAO. 36 p. FAO Fisheries Synopsis, no. 158.

DINESH, K., NANDEESHA, M.C., NAUTIYAL, P. and AIYYAPPA, P., 2010. Mahseers in India: a review with focus on conservation and management. The Indian Journal of Animal Sciences, vol. 80, pp. 26-38.

DRINAN, T.J., MCGINNITY, P., COUGHLAN, J.P., CROSS, T.F. and HARRISON, S.S., 2012. Morphological variability of Atlantic salmon Salmo salar and brown trout Salmo trutta in different river environments. Ecology Freshwater Fish, vol. 21, no. 3, pp. 420-432. http://dx.doi.org/10.1111/j.1600-0633.2012.00561.x.

GOULDING, M., CARVALHO, M.L. and FERREIRA, E.G., 1988. Rio Negro: Rich life in poor water. Hague, the Netherlands: SPB Academic Publishing.

HASAN, Z., AHMAD, I., YOUSUF, M., REHMAN, L. and KHAN, J., 2013. Fish Biodiversity of River Swat. Pakistan Journal of Zoology, vol. 45, pp. 283-289.

HECKEL, J. J., 1838. Fische aus caschmir gesammelt und herausgegeben. In: C.F. von Hugel and J.J. Heckel, editors. Annals and Magazine of Natural History (Series 8). Wien, pp. 1-112.

HEINS, D.C., BAKER, J.A. and GUILL, J.M., 2004. Seasonal and interannual components of intrapopulation variation in clutch size and egg size of a darter. Ecology Freshwater Fish, 
vol. 13, no. 4, pp. 258-265. http://dx.doi.org/10.1111/j.16000633.2004.00064.x.

HORA, S.L., 1939. The game fishes of India VIII. The mahseer or the large scaled Barbels of India. 1. The putitor mahseer, Barbus Tor putitora (Hamilton). Journal of the Bombay Natural History Society, vol. 41, pp. 272-285.

JAYARAM, K.C., 1981. The freshwater fishes of India, Pakistan, Bangladesh, Burma, Sri Lanka: A handbook. Calcutta: Zoological Survey of India.

JOSHI, K.D., DAS, S.C.S., PATHAK, R.K., KHAN, A., SARKAR, U.K. and ROY, K., 2018. Pattern of Reproductive Biology of the Endangered Golden Mahseer Tor putitora (Hamilton, 1822) with Special Reference to Regional Climate Change Implications on Breeding Phenology from Lesser Himalayan region, India. Journal of Applied Animal Research, vol. 46, no. 1, pp. 1289-1295. http:// dx.doi.org/10.1080/09712119.2018.1497493.

LANGER, S., TRIPATHI, N. K., and KHAJURIA, B., 2013. Morphometric and meristic study of Golden Mahseer (Tor Putitora) from Jhajjar Stream (JandK), India. Research Journal of Animal. Veterinary and Fishery Science, vol. 1, no. 7, pp. 2320-6535.

SATI, J., KUMAR, R., SAHOO, P.K., PATIYAL, R.S., ALI, S. and BARAT, A., 2013. Genetic characterization of Golden Mahseer (Tor putitora) populations using mitochondrial DNA markers. Mitochondrial DNA, vol. 26, no. 1, pp. 68-74. http://dx.doi.org/10.3109/19401 736.2013.823170. PMid:24020997.

KARR, J.R., FAUSCH, K.D., ANGERMEIER, P.L., YANT, P.R. and SCHLOSSER, I.J., 1986. Assessing Biological Integrity in Running Waters: A Method and Its Rationale, Illinois Natural History Survey. Champaigne, IL: Special Publication.

KHAN, A.R., 2001. Analysis of hydro-meteorological time series: Searching evidence for climaticchange in the Upper Indus Basin. Lahore, Pakistan: International Water Management Institute. IWMI working paper, n. 23.

KHAN, A., SHAKIR, H., KHAN, M., ABID, M. and MIRZA, M., 2008. Ichthyofaunal survey of some freshwater reservoirs in Punjab. The Journal of Animal and Plant Sciences, vol. 18, pp. 151.

KHAJURIA, B. and LANGER, S., 2016. Distribution record on abundance of Tor putitora in Jammu waters. IJFAS, vol. 4, no. 1, pp. 341-347.

KHARE, P., MOHINDRA, V., BARMAN, A.S., SINGH, R.K. and LAL, K.K, 2014. Molecular evidence to reconcile taxonomic instability in mahseer species (Pisces: Cyprinidae) of India. Organisms, Diversity E Evolution, vol. 14, no. 3, pp. 307-326. http://dx.doi. org/10.1007/s13127-014-0172-8.

LAKRA, W.S., SARKAR, U.K., KUMAR, R.S., PANDEY, A., DUBEY, V.K. and GUSAIN, O.M., 2010. Fish diversity, habitat ecology and their conservation and management issues of a tropical River in Ganga basin, India. The Environmentalist, vol. 30, no. 4, pp. 306-319. http://dx.doi.org/10.1007/s10669-010-9277-6.

LANGERHANS, R.B., 2008. Predictability of phenotypic differentiation across flow regimes in fishes. Integrative and Comparative Biology, vol. 48, no. 6, pp. 750-768. http://dx.doi.org/10.1093/ icb/icn092. PMid:21669830.

LATIF, M., SIDDIQUI, S., MINHAS, I.K., LATIF, S., 2016. Studies on ichthyofaunal diversity of Head Qadirabad, River Chenab, Punjab, Pakistan. IJFAS, vol. 4, pp. 25-29.

MALIK, D.S. and NEGI, K.S., 2007. Mahseer fish: Bionomics and population. Delhi: Daya Publishing House, 231p.

MENON, A.G.K., 1992. Taxonomy of the Mahseer fishes of Genus Tor Gray with description of new species from Deccan. Journal of the Bombay Natural History Society, vol. 89, pp. 210-228.
MIRZA, M.R., 2004. Status of Golden Mahseer (Pisces: Cyprinidae) of the Indus River System. Record of Zoological Survey of Pakistan, vol. 15, pp. 42-44.

MIRZA, M.R., 1973. Aquatic fauna of Swat Valley, Pakistan, Part 1: fishes of Swat and adjoining areas. Biologia, vol. 19, pp. 119-144.

MIRZA, M.R., 1967. Tor zhobensis sp. Nov. a new mahseer from the River Zhob, West Pakistan. Pakistan Journal of Science, vol. 19, pp. 54-57.

MIRZA, M.R. and JAVED, M.N., 1986. A contribution to the fishes of the genus Tor Gray (Pisces: Cyprinidae) from Pakistan and Azad Kashmir. Biologia, vol. 32, pp. 71-82.

MIRZA, M.R. and JAVED, M.N., 1985. A note on Mahseer of Pakistan with the description of Naziritor, a new subgenus (Pisces: cyprinidae. Pakistan Journal of Zoology, vol. 17, pp. 225-227.

MIRZA, Z., JAVED, M. and MIRZA, M., 2006. Fishes of the river Jhelum from Mangla to Jalalpur near head Rasool. Biologia, vol. 52, pp. 215-227.

MOESER, A.A. and BERMINGHAM, E., 2005. Isolation and characterization of eight microsatellite loci for the Neotropical freshwater catfish Pimelodella chagresi (Teleostei: pimelodidae. Molecular Ecology Notes, vol. 5, no. 2, pp. 363-365. http://dx.doi. org/10.1111/j.1471-8286.2005.00928.x.

MORRISON, W.R. 3rd., LOHR, J.L., DUCHEN, P., WILCHES, R., TRUJILLO, D., MAIR, M. and RENNER, S.S., 2009. The impact of taxonomic change on conservation: does it kill, can it save, or is it just irrelevant. Biological Conservation, vol. 142, no. 12, pp. 3201-3206. http://dx.doi.org/10.1016/j.biocon.2009.07.019.

NG, C.K., 2004. Kings of the Rivers: Mahseer in Malaysia and the Region. Selangor: Inter Sea Fishery (M) Pte Ltd.

Food and Agriculture Organization - FAO, 2011 [viewed 06 August 2019]. AQUASTAT Transboundary River Basins - Indus River Basin. Rome, Italy: Food and Agriculture Organization of the United Nations (FAO). Available from: http://www.fao.org/3/ ca2136en/CA2136EN.pdf

PANDIT, M.K. and GRUMBINE, R.E., 2012. Potential effects of ongoing and proposed, hydropower development on terrestrial biological diversity in the Indian Himalaya. Conservation Biology, vol. 26, no. 6, pp. 1061-1071. http://dx.doi.org/10.1111/j.15231739.2012.01918.x. PMid:22985327.

PERVAIZ, K., IQBAL, Z., MIRZA, M.R., JAVED, M.N. and NAEEM, M., 2012. Meristic and Morphometric Studies on Indus Mahseer Tor macrolepis (Teleostei: Cyprinidae) from District Attock, Pakistan. International Journal of Agriculture and Biology, vol. 14, pp. 169-175.

PINDER, A.C., MANIMEKALAN, A., KNIGHT, J.D.M., KRISHNANKUTTY, P., BRITTON, J.R., PHILIP, S., DAHANUKAR, N. and RAGHAVAN, R., 2018. Resolving the taxonomic enigma of the iconic game fish, the hump-backed mahseer from the Western Ghats biodiversity hotspot, India. PLoS One, vol. 13, no. 6, pp. 6. http://dx.doi.org/10.1371/journal.pone.0199328. PMid:29924871.

RAFIQUE, M.Z. and JAVED, H.I., 2002. Fish fauna of Swat and Buner valley. Records of Zoological Survey of Pakistan, vol. 14, pp. 43-49.

SAEED, K., KHAN, S. and HAQ F., 2013. Diversity and population status of fish fauna of River Barandu District Buner Khyber Pakhtunkhwa Province, Pakistan. Journal of Biological and Environmental Sciences, vol. 3, pp. 83-88.

SALMA, S. and REHMAN, M.A.S., 2012. Rainfall trends in different climate zones of Pakistan. Pakistan Journal of Meteorology, vol. 19, pp. 17-34. 
SARKAR, U.K., MAHAPATRA, B.K., SAXENA, S.R. and SINGH, A.K., 2015. Mahseer in India: an overview on research status and future priorities.J Ecophysiology Occup Health., vol. 15, pp. 45-52.

SARMA, D., AKHTAR, M.S. and SINGH, A.K., 2014. Mahseer Research and Development: A Journey by DCFR. Uttarakhand, India: ICARDirectorate of Cold Water Fisheries Research Bhimtal. DCFR publication Manual.

SARMA, D., DAS, P., DAS, P., SANWA, S. and AKHTAR, M.S., 2015. Nutritional Composition of Golden Mahseer (Tor putitora) in Coldwater Himalayan Region of India. SKUAST Journal of Research, vol. 17, pp. 23-28.

SARMA, D., HALDAR, R.S., DAS, P. and MAHANTA, P.C., 2010. Management in seed production of golden mahseer, Tor putitora in hatchery conditions. Aquaculture Asia., vol. 4, pp. 31-35.

SCHEINER, S.M., 1993. Genetics and evolution of phenotypic plasticity. Annual Review of Ecology and Systematics, vol. 24, no. 1, pp. 35-68. http://dx.doi.org/10.1146/annurev. es.24.110193.000343.

SCHLICHTING, C.D., 1986. The evolution of phenotypic plasticity in Plants. Annual Review of Ecology and Systematics, vol. 17, no. 1, pp. 667-693. http://dx.doi.org/10.1146/annurev.es.17.110186.003315.

SCHRECK, C.B. and MOYLE, P.B., 1990. Method for fish biology. Bethesda, Maryland: American Fisheries Society. http://dx.doi. org/10.47886/9780913235584.
SEN, T.K. and JAYARAM, K.C., 1982. The Mahseer Fish of India - A review. Rec. Zoological Survey of India. Vol. 39, pp. 1-38.

SHAKIR, A.S., REHMAN, H. and EHSAN, S., 2010. Climate change impact on river flows in chitral watershed. Pakistan Journal of Engineering and Applied Sciences, vol. 7, pp. 211-234.

SHARMA, K.K., MOHAN, V.C. and KOUSER, U., 2015. Comparative accounts of merestic count and morphometric measure- ments of Golden mahseer (Tor putitora) among Chenani hydroelectric dam, Jhajjar stream and Dansar stream (J\&K) India. Indian Journal of Applied Research, vol. 5, pp. 772-774.

SHRESTHA, T.K., 1990. Rare fishes of Himalayan waters of Nepal. Journal of Fish Biology, vol. 37, no. sa, pp. 213-216. http://dx.doi. org/10.1111/j.1095-8649.1990.tb05042.x.

TALWAR, P.K. and JHINGRAN, A.G., 1991. Inland Fisheries of India and Adjacent Countries. Calcutta: Oxford and I B H Publication Co. Vol. 1 and 2 .

VIDALIS, K. and TSIMENIDIS, N., 1996. Age determination and growth of picarel (Spicara smaris) from the Cretan continental shelf (Greece. Fisheries Research, vol. 28, no. 4, pp. 395-421. http:// dx.doi.org/10.1016/S0165-7836(96)00488-2.

YOUSAFZAI, A.M., KHAN, W. and HASAN, Z., 2013. Fresh records on water quality and Ichthyodiversity of River Swat at Charsadda, Khyber Pakhtunkhwa. Pakistan Journal of Zoology, vol. 45, pp. 1727-1734. 